\title{
A LOGISTIC REGRESSION ANALYSIS OF FACTORS AFFECTING ENROLLMENT DECISIONS OF PROSPECTIVE STUDENTS OF DISTANCE EDUCATION PROGRAMS IN ANADOLU UNIVERSITY
}

\author{
Dr. Oznur OZTURK \\ ORCID: https://orcid.org/0000-0002-9739-2025 \\ Open Education Faculty, Anadolu University \\ Eskisehir, Turkey
}

Received Date: 13/06/2017 Accepted Date: 31/07/2018

\section{ABSTRACT}

Some prospective students placed by the Assessment, Selection and Placement Center (OSYM) to associate and undergraduate programs in the Faculty of Open Education of Anadolu University enroll in these programs, while others do not. A decision to enroll may be affected by the following variables: the prospective student's gender, educational status, plans for retaking the university entrance exam, the number of times they took the entrance exam, marital status, employment status, household income, parents' level of education, and age. The aim of this study is to use the above-mentioned variables to develop a model that will help classify prospective students placed on the distance education programs of Anadolu University into two groups, i.e. students who are more likely to enroll and those who are not; and to discuss the potential benefits of the model in the administrative processes. Students assigned by OSYM in the 2015-2016 academic year to the distance education programs of Anadolu University comprise the population of this study, which is a finite population consisting of 178.229 people. Data were collected via an online survey. The survey included items on demographics, enrollment status, and the above-mentioned variables. A total of 1.829 students completed the survey, of which 1.117 enrolled and 712 did not. Data were analyzed using the SPSS 22.0 software package. Binary logistic regression analysis was used to develop a model to classify the students as enrollees and non-enrollees. Education status, marital status, plans to retake the university entrance exam, the number of times the entrance exam was taken, employment status, and age were found to affect the prospective students' decision to enroll.

Keywords: Distance education, decision to enrollment, enrollment in distance education programs, logistic regression, binary logistic regression.

\section{INTRODUCTION}

Distance education is a learning system in which the students are able to participate educational activities by making use of printed materials as well as a rich variety of communicational technologies without a limitation in the time and space, and they have access to the synchronous and asynchronous educational sources and contents (Acik ve Uzaktan Ogrenme Sozlugu, 2018). Technology is a crucial element of distance education (Bates, 2008).

Distance education is a common practice in Turkey like many others in the world to meet the higher education demand and to achieve equality of opportunity in education. In Turkish higher education system, distance education methods have been used since 1970s. The first phases of distance education in Turkey were "Correspondence Education" and "Common Higher Education İnstitution" (Abbr. YAYKUR), which 
were initial higher education practices far from reaching the masses. Although these programs were highly demanded, they could not be sustained. İn 1981, 420 thousand students were willing to continue their education in higher education institutions, while only 54 thousand of them could be accepted to universities. The universities were able to meet 13 percent of the demand (Acikogretim Sistemi, 2017). On the other hand, the advance in educational technologies made the idea of distance learning system an urgent obligation. The idea of high-standard higher education with the principle of equal opportunity was embodied in the Open Education Faculty of Anadolu University in 1982-1983 semester for the first time in Turkey. 29500 students enrolled in the Economics and Business Management Program in the very first year, and this revealed the necessity and demand of higher education (Acikogretim Sistemi, 2017).

The educational process, which started with the "Business Management and Economics program in Open Education Faculty in 1982 in Anadolu University, continued with the establishment of Faculty of Economics and Administrative Sciences in 1993. Students who want to enroll in Open and Distance Education system in Anadolu University have to take Assessment Selection and Placement Center's (OSYM) examination. Foreign students and the students who want to have a second university degree, a vertical transfer or an undergraduate transfer have to take ANADOLUYOS examination (Sahin, 2017). The graduates of high schools and their equivalents can apply OSYM for the departments and programs of Open Education, Economics and Administration Faculties, be placed to them with or without an exam, and apply and enroll the related programs in the dates the related faculties determine (Anadolu Universitesi, 2017).

İn 2016, Gumus and Firat made a research on the motives of students of Anadolu University Open Education System to prefer open and distance education. İn the scope of this research they collected data from 4247 open education students, and found out that their motives in order of priorities were as follows: Flexibility of time, flexibility of space, and new career opportunities. Aksarayli and Pala's 2017 research with the title "Cluster Analysis of the Correlation between Motives in Preferring Distance Education and Success" was based on the questionnaires conducted with distance education students of Dokuz Eylul University. The questions focused on their educational success and motives to prefer distance education. 285 students answered the questionnaire, and their motives were as follows: "Distance education's contribution to the student's career", "the opportunity to work and study at the same time", "expectation of high academic benefit", and "ease of access".

By the 2015-2016 school year, the Faculty of Open Education and the Faculty of Economics and Administrative Sciences in Anadolu University had 51 programs (17 undergraduate programs and 34 associate degree programs), to which 2905666 (1435754 active and 1469912 passive) students were enrolled. Every year, a part of the candidates placed to the programs by OSYM prefer not to enroll. In 20152016, for example, 31588 of 178229 candidates $(17,72 \%)$ preferred not to enroll to the programs they were accepted. The Statistical Data Acquisition and Evaluation Unit of the Open Education Faculty in Anadolu University conducts various surveys on the study methods, student satisfaction in office services, call center, textbooks, demographic data, tests, e-book application, -e-learning portal, video-lectures, training questions, grading system, audiobook application and instructional programs on TV. Students' opinions are gathered, analyzed, and the results are published.

These surveys can access various detailed information on the students who enrolled in the programs, however, the data on the motives of preference in terms of enrolling or not enrolling to the programs are still lacking. This study aims at determining the motives of the students for enrolling or not enrolling the programs they are placed, and at categorizing the students according to these variables. Logistic regression is the appropriate method to analyze the case, since the dependent variable consists of two levels of evaluation, i.e. enrolling or not enrolling. 
Categorical variables with nominal and ordinal scales are frequently used in many fields, particularly in social sciences, educational sciences and medical sciences. İn a multivariate statistical analysis of causal relationships using categorical data, logistic regression analysis is preferred for the following reasons:

$>$ Examining causal relationships between variables is an important scientific goal, applicable in daily life. In this respect, the type of the relationship between the variables, and the mathematical equation that could be used to express this relationship are important areas of study.

$>$ When the dependent variable studied is categorical, logistic regression analysis is preferred, as the goal is to predict the value of the dependent variable, in other words, to classify units into categories and investigate the relationship between the dependent variable and the independent variable(s).

$>$ When the dependent variable is measured using a nominal scale, independent variables can be discrete or continuous (Tabachnick and Fidell, 2001). Therefore, logistic regression analysis is superior to multiway frequency analysis.

$>$ Assumptions concerning the distribution and linearity of the data or the equality of variances are not required in logistic regression analysis. Therefore, compared to simple and multiple regression analysis or discriminant analysis, logistic regression analysis provides the researcher with significant flexibility (Albayrak, 2009).

$>$ Logistic regression analysis provides a flexible model, and it is easy to interpret. These features increase the popularity of the method (Tatlidil, 1996).

$>$ Various software packages are available for conducting logistic regression analysis.

$>$ Logistic regression analysis does not produce negative probabilities. All probability values are positive and range from 0 to 1 (Cokluk, 2010).

\section{METHOD}

\section{Population and Sample}

The population of the study was a finite population comprising 178.229 students placed in 2015-2016 academic year by OSYM in associate and undergraduate programs of Anadolu University's Open Education, Economics, and Business Administration Faculties. Of the prospective students placed, 146.641 enrolled in their programs, whereas 31.588 did not. However, 111 students were removed from the population, as they could not be contacted because their contact information was missing or incorrect. Thus, the number of students who did not enroll was revised to 31.477 and the population to 178.118 . The smallest sample size that can be selected based on the $4 \%$ error rate at the $99 \%$ confidence level of the population, where approximately 180,000 people are involved, was identified as 1.035 .

\section{Data Collection and Analysis}

An online questionnaire was developed to collect data on the variables that could be used in a model to predict the decision to enroll among students who were placed in distance education programs of Anadolu University. The questionnaire contained demographic items, as well as items on the variables reported in Appendix 1. The link for accessing the online questionnaire was sent via SMS to the cell phones of 10.330 students randomly selected from among the 31.477 prospective students who did not enroll. For students who enrolled (146.641 students), a link to the online questionnaire was provided via their university accounts, which they could access using their student IDs and passwords. A total of 712 enrollees and 1.117 non-enrollees completed the questionnaire. Thus, a response rate close to the target sample size of 1.142 was obtained. The data gathered by the questionnaires conducted were processed by SPSS 22.0 software. Binary logistic regression analysis was used to classify the students placed into two groups (enrolled and unenrolled) and to determine the relationship between dependent and independent variables (Cokluk, Sekercioglu ve Buyukozturk, 2014). Binary logistic regression analysis is a method which is used in the cases where 
dependent variables entails two possible answers, and which reveals the relation between one or more explanatory variables and binary answer variables (Ozdamar, 2015).

Logistic regression analysis does not necessitate to respond to any hypothesis on the distribution of independent variables. However, there are some crucial requirements in its use. One of these requirements is the number of subjects analyzed in variables. In the cases that the number of subjects were not sufficient in categorical variables such as educational background, marital status, educational background of parents and employment status, proper assessment levels were combined. Another requirement is about the extreme values of predictor variable. İn order to meet this requirement, standard errors were examined and found out to be in the required range. Stable findings can be achieved with fifty subjects per each independent variable in logistic regression analysis. This is why the study focused on a large sample. Finally, the findings of the logistic regression model were evaluated with the assumption that there are no linear correlations among independent variables (Cokluk, 2010). The phases of the analysis process are presented in detail below.

\section{FINDINGS}

As was mentioned previously, this study uses logistic regression analysis to identify the factors that affect enrollment decisions of prospective students placed by OSYM to the distance education programs of Anadolu University, and uses these variables to classify prospective students into enrollees and non-enrollees. Binary logistic regression was used because the dependent variable of enrollment has two categories: enrollment and non-enrollment. Frequency distributions of the variables identified in Appendix 1 are reported in Appendix 2. The frequency table in Appendix 2 shows that $54.2 \%$ of the respondents were male, and $61.3 \%$ were high school seniors or graduates. In terms of marital status, $57.6 \%$ were not married, and $39.5 \%$ were married. $25.4 \%$ of the prospective students who completed the survey had two children in their families, $27.4 \%$ had three children in their families, and 39.6\% had four or more children in their families. İn terms of the parents' education, $73.7 \%$ of mothers and $53.5 \%$ of fathers were elementary school graduates or did not receive any formal education. $65.0 \%$ of the respondents claimed that they were planning to retake the university entrance exam. Of the respondents, $29.1 \%$ took the entrance exam three times or more, $26.4 \%$ took the exam twice and $26.1 \%$ took the exam once, excluding the current year. In $2015,18.4 \%$ took the entrance exam for the first time, while $69.6 \%$ of the respondents were reported as employed and $36.9 \%$ employed for five years or less. As far as the respondents are concerned, $15.1 \%$ had a household income below the minimum wage, while $44.0 \%$ had a household income between 1,000 and 2,000 Turkish liras. A majority of the respondents, $30.6 \%$, lived in the Marmara region. The average age of the respondents was 27.67.

\section{Identifying the Variables to be Included in the Model}

A chi-square test (for the age variable, a t-test) was conducted to see if the dependent variable of enrollment was related to each of the variables reported in Appendix 1. Test results are reported in Table 1. Variables that meet the criterion of $\mathrm{p}<0.05$ based on these results, marked with a circle, are statistically significant. These variables will be included in the binary logistic regression model to classify prospective students as enrollees and non-enrollees.

Table 1. Test Results for the Relationship between Enrollment and Independent Variables

\begin{tabular}{lll}
\hline Variable & Pearson's Chi-Square & $\mathrm{p}$ \\
\hline Gender & 2.024 & 0.155 \\
Education status & 40.363 & 0.000 \\
Marital status & 13.894 & 0.001 \\
\hline
\end{tabular}




$\begin{array}{lll}\begin{array}{l}\text { Number of children in the family (including the } \\ \text { respondent) }\end{array} & 3.523 \\ \text { Mother's education level } & 6.131 \\ \text { Father's education level } & 11.86 \\ \text { Plans to retake the exam } & 116.055 \\ \text { How many times the exam was taken (excluding the } & 12.243 \\ \text { current year) } & 26.82 \\ \text { Employment status } & 44.898 \\ \text { Years employed } & 13.301 \\ \text { Monthly household income } & 8.379 \\ \text { Place of Residence } & \mathrm{t} \text { value }(=-5.709) \\ \text { Age } & \end{array}$

\section{Estimating the Initial Model}

As was explained above, the model was developed using likelihood ratios and backward elimination (Backward: LR).The initial model contains only the constant term. This model is estimated so that its results can be compared with the results of the binary logistic regression model to be estimated in the next step. If the value of the -2LL statistic for the binary logistic regression model estimated is significantly different from the -2LL value of the initial model, it indicates that independent variables in the binary logistic regression model can explain the dependent variable. The minimum value of the -2LL statistic is 0 . Estimated values of the initial model are reported in Table 2. -2LL values in the table are very large in all three iterations.

Table 2. Initial Model (Block 0)

\begin{tabular}{|c|c|c|c|}
\hline İteration & & -2 Log Likelihood (-2LL) & $\begin{array}{l}\text { Coefficients } \\
\text { Constant }\end{array}$ \\
\hline \multirow{3}{*}{ Step 0} & 1 & 2445.129 & .443 \\
\hline & 2 & 2445.105 & .450 \\
\hline & 3 & 2445.105 & .450 \\
\hline
\end{tabular}

Classification table of the initial model, which contained only the constant term, is reported in Table 3. As the table shows, the rate of correct classification is $61.1 \%$. Because the number of enrollees are more than that of non-enrollees, this model classifies all prospective students as enrollees.

Table 3. Classification Table of the Initial Model

\begin{tabular}{llcccc}
\hline \multirow{2}{*}{ Observed } & & $\begin{array}{l}\text { Estimated } \\
\text { Enrollment Status } \\
\text { Non-enrollee }\end{array}$ & Enrollee & $\begin{array}{l}\text { Percentage of } \\
\text { Correct } \\
\text { Classification }\end{array}$ \\
\hline \multirow{3}{*}{ Step 0 } & Enrollment & Non-enrollee & 0 & 712 & 0.0 \\
& Status & Enrollee & 0 & 1117 & 100.0 \\
& Total Percentage & & & & 61.1 \\
\hline
\end{tabular}

Table 4 reports the constant term, standard error of the constant term; the value of the Wald statistic to test the significance of the variable; degrees of freedom, significance level, and exponential logistic regression 
coefficient (odds) for the initial model. The constant term can be said to be significant, as the significance level of the initial model is smaller than 0.05 .

Table 4. Variables in the Initial Model

\begin{tabular}{|c|c|c|c|c|c|c|c|}
\hline & & B & S.E. & Wald & $\mathrm{df}$ & Sig. & $\operatorname{Exp}(B)$ \\
\hline Step 0: & Constant & .450 & .048 & 88.180 & 1 & .000 & 1.569 \\
\hline
\end{tabular}

Table 5 reports the independent variables that were not included in the initial model. The first category of each categorical variable in the model was defined as the reference category. Independent variables with significance levels smaller than 0.05 , marked with an $*$, are the independent variables that will be included in the model.

Table 5. Variables Not Included in the Initial Model

\begin{tabular}{|c|c|c|c|c|}
\hline & Variables & Score & sd & $\mathrm{p}$ \\
\hline \multirow{28}{*}{ Step 0: } & EdStatus & 40.363 & 5 & $0.000^{*}$ \\
\hline & EdStatus(1) & 23.549 & 1 & $0.000^{*}$ \\
\hline & EdStatus(2) & 1.004 & 1 & 0.316 \\
\hline & EdStatus(3) & 17.509 & 1 & $0.000^{*}$ \\
\hline & EdStatus(4) & 9.538 & 1 & $0.002^{*}$ \\
\hline & EdStatus(5) & 2.248 & 1 & 0.134 \\
\hline & MarStatus & 13.894 & 2 & $0.001^{*}$ \\
\hline & MarStatus(1) & 2.93 & 1 & 0.087 \\
\hline & $\operatorname{MarStatus}(2)$ & 9.239 & 1 & $0.002^{*}$ \\
\hline & FatherEd & 11.86 & 5 & $0.037^{*}$ \\
\hline & FatherEd(1) & 5.815 & 1 & $0.016^{*}$ \\
\hline & FatherEd(2) & 4.525 & 1 & $0.033^{*}$ \\
\hline & FatherEd(3) & 1.362 & 1 & 0.243 \\
\hline & FatherEd(4) & 1.959 & 1 & 0.162 \\
\hline & FatherEd(5) & 1.334 & 1 & 0.248 \\
\hline & PlanRetake(1) & 116.055 & 1 & $0^{*}$ \\
\hline & TimesTaken & 12.243 & 3 & $0.007^{*}$ \\
\hline & TimesTaken(1) & 0.086 & 1 & 0.769 \\
\hline & TimesTaken(2) & 0.082 & 1 & 0.774 \\
\hline & TimesTaken(3) & 8.43 & 1 & $0.004^{*}$ \\
\hline & EmpStatus & 26.82 & 3 & $0^{*}$ \\
\hline & EmpStatus(1) & 1.892 & 1 & 0.169 \\
\hline & EmpStatus(2) & 13.792 & 1 & $0^{*}$ \\
\hline & EmpStatus(3) & 0.108 & 1 & 0.743 \\
\hline & EmpYears & 44.898 & 4 & $0^{*}$ \\
\hline & EmpYears(1) & 1.826 & 1 & 0.177 \\
\hline & EmpYears(2) & 6.731 & 1 & $0.009^{*}$ \\
\hline & EmpYears(3) & 24.521 & 1 & $0^{*}$ \\
\hline
\end{tabular}




\begin{tabular}{llll} 
EmpYears(4) & 20.235 & 1 & $0^{*}$ \\
MonthIncome & 13.301 & 3 & $0.004^{*}$ \\
MonthIncome(1) & 3.74 & 1 & 0.053 \\
MonthIncome(2) & 8.206 & 1 & $0.004^{*}$ \\
MonthIncome(3) & 2.394 & 1 & 0.122 \\
age & 32.06 & 1 & $0^{*}$ \\
\hline
\end{tabular}

\section{Estimating the Binary Logistic Regression Model}

Using the backward elimination method, the binary logistic regression was created in three steps. Results of the Omnibus test concerning model coefficients are reported in Table 6. The table shows that results of the chi-square tests for models created at each step were significant $(\mathrm{p}<0.05)$, indicating that these models were better than the initial model that contained only the constant term. In other words, the hypothesis of similarity between the initial model and the binary logistic regression model is rejected.

Table 6. Omnibus Test for Model Coefficients

\begin{tabular}{lllll}
\hline & & Chi-square & sd & $\mathrm{p}$ \\
\hline \multirow{3}{*}{ Step 1: } & Step & 241.373 & 26 & .000 \\
& Block & 241.373 & 26 & .000 \\
& Model & 241.373 & 26 & .000 \\
Step 2: & Step & 3.862 & 3 & .277 \\
& Block & 237.511 & 23 & .000 \\
& Model & 237.511 & 25 & .000 \\
Step 3: & Step & -4.471 & 3 & .215 \\
& Block & 233.039 & 20 & .000 \\
& Model & 233.039 & 22 & .000 \\
\hline
\end{tabular}

Values reported in Table 7 indicate how much of the variance in dependent variable is explained by independent variables included in the model. The binary logistic regression model obtained in the 3rd step explains $16.2 \%$ of the variance in the dependent variable of enrollment.

Table 7. Model Summary

\begin{tabular}{llll}
\hline Step & $-2 \log$ likelihood & $\begin{array}{l}\text { Cox \& Snell R } \\
\text { Square }\end{array}$ & $\begin{array}{l}\text { Nagelkerke } \\
\text { R Square }\end{array}$ \\
\hline 1 & $2203.732^{\mathrm{a}}$ & .124 & .168 \\
2 & $2207.594^{\mathrm{a}}$ & .122 & .165 \\
3 & $2212.065^{\mathrm{a}}$ & .120 & .162 \\
\hline
\end{tabular}

Model-data fit is examined using the Hosmer and Lemeshow chi-square test for goodness of fit, which evaluates the fit of the logistic regression model as a whole. If the result of this test is insignificant, it indicates that model-data fit is good. Table 8 shows that the $\mathrm{p}$ value of the logistic regression model obtained in step 3 is 0.921 , which is insignificant because it is larger than 0.05 , indicating good model-data fit. 
Table 8. Hosmer and Lemeshow Test

\begin{tabular}{llll}
\hline Step & Chi-square & sd & $\mathrm{p}$ \\
\hline 1 & 11.127 & 8 & .195 \\
2 & 7.768 & 8 & .456 \\
3 & 3.202 & 8 & .921 \\
\hline
\end{tabular}

The classification table reported in Table 9 shows that the binary logistic regression model created using the backward elimination method has correctly classified 310 of the 712 students who did not enroll, and incorrectly classified 402, with a correct classification rate of 43.5\%. The model incorrectly classified 217 of 1,117 students who enrolled, and correctly classified 900 , with a correct classification rate of $80.6 \%$. Overall, $66.2 \%$ of students were correctly classified.

Table 9. Classification Table Generated by the Logistic Regression Model

\begin{tabular}{|c|c|c|c|c|c|}
\hline \multirow{3}{*}{ Observed } & & & \multicolumn{3}{|l|}{ Estimated } \\
\hline & & & \multicolumn{2}{|c|}{ Enrollment Status } & \multirow{2}{*}{$\begin{array}{l}\text { Percentage of } \\
\text { Correct } \\
\text { Classification }\end{array}$} \\
\hline & & & Non-enrollee & Enrollee & \\
\hline \multirow{3}{*}{ Step 1} & \multirow[t]{2}{*}{ Enrollment Status } & $\begin{array}{l}\text { Non- } \\
\text { enrollee }\end{array}$ & 328 & 384 & 46.1 \\
\hline & & Enrollee & 218 & 899 & 80.5 \\
\hline & Total Percentage & & & & 67,1 \\
\hline \multirow{3}{*}{ Step 2} & Enrollment Status & $\begin{array}{l}\text { Non- } \\
\text { enrollee }\end{array}$ & 326 & 386 & 45.8 \\
\hline & & Enrollee & 222 & 895 & 80.1 \\
\hline & Total Percentage & & & & 66.8 \\
\hline \multirow{3}{*}{ Step 3} & Enrollment Status & $\begin{array}{l}\text { Non- } \\
\text { enrollee }\end{array}$ & 310 & 402 & 43,5 \\
\hline & & Enrollee & 217 & 900 & 80,6 \\
\hline & Total Percentage & & & & 66.2 \\
\hline
\end{tabular}

Table 10 reports the coefficients of the variables included in the logistic regression model developed, standard errors for these coefficients, Wald statistics, degrees of freedom, $\mathrm{p}$ values, and exponential coefficient $\operatorname{Exp}(\beta)$ values. In the logistic regression model, $\operatorname{Exp}(\beta)$ values are used to interpret the coefficients. $\operatorname{Exp}(\beta)$ values indicate change in likelihood as a result of one unit change in the relevant variable (Hair et. al., 2010; Field, 2013). $\operatorname{Exp}(\beta)$ values were interpreted for variables that are statistically significant at 0.05 level of significance, marked with dark background in the following table. 
Table 10. Coefficient Estimates of the Variables Included in the Logistic Regression Model

\begin{tabular}{|c|c|c|c|c|c|c|c|c|c|}
\hline & & 凶 & Standard & Wald & $s d$ & $\mathrm{p}$ & $\operatorname{Exp}(\mathbb{\otimes})$ & $\begin{array}{l}95 \% \mathrm{cc} \\
\text { interval }\end{array}$ & $\begin{array}{l}\text { dence } \\
\operatorname{Exp}(\mathbb{\nabla})\end{array}$ \\
\hline & & & & & & & & Lower & Upper \\
\hline & EdStatus & & & 28.987 & 5 & .000 & & & \\
\hline & EdStatus(1) & .087 & .155 & .317 & 1 & .573 & 1.091 & .805 & 1.480 \\
\hline & EdStatus(2) & -.371 & .279 & 1.763 & 1 & .184 & .690 & .399 & 1.193 \\
\hline & EdStatus(3) & -.524 & .187 & 7.805 & 1 & .005 & .592 & .410 & .855 \\
\hline & EdStatus(4) & -.773 & .227 & 11.551 & 1 & .001 & .462 & .296 & .721 \\
\hline & EdStatus(5) & -.068 & .245 & .077 & 1 & .782 & .934 & .578 & 1.510 \\
\hline & MarStatus & & & 9.984 & 2 & .007 & & & \\
\hline & MarStatus(1) & -.342 & .144 & 5.647 & 1 & .017 & .711 & .536 & .942 \\
\hline & MarStatus(2) & .541 & .387 & 1.950 & 1 & .163 & 1.717 & .804 & 3.668 \\
\hline & FatherEd & & & 18.208 & 5 & .003 & & & \\
\hline & FatherEd(1) & .467 & .389 & 1.440 & 1 & .230 & 1.596 & .744 & 3.424 \\
\hline & FatherEd(2) & -.150 & .340 & .194 & 1 & .659 & .861 & .442 & 1.677 \\
\hline Sten 3. & FatherEd(3) & -.064 & .355 & .033 & 1 & .856 & .938 & .468 & 1.878 \\
\hline & FatherEd(4) & .322 & .350 & .842 & 1 & .359 & 1.379 & .694 & 2.741 \\
\hline & FatherEd(5) & .227 & .378 & .359 & 1 & .549 & 1.254 & .598 & 2.632 \\
\hline & PlanRetake(1) & 1.216 & .117 & 108.542 & 1 & .000 & 3.375 & 2.685 & 4.243 \\
\hline & TimesTaken & & & 8.085 & 3 & .044 & & & \\
\hline & TimesTaken(1) & -.244 & .161 & 2.306 & 1 & .129 & .784 & .572 & 1.073 \\
\hline & TimesTaken(2) & -.174 & .174 & 1.002 & 1 & .317 & .840 & .597 & 1.182 \\
\hline & TimesTaken(3) & -.470 & .180 & 6.846 & 1 & .009 & .625 & .439 & .889 \\
\hline & EmpStatus & & & 14.091 & 3 & .003 & & & \\
\hline & EmpStatus(1) & .376 & .189 & 3.972 & 1 & .046 & 1.457 & 1.006 & 2.108 \\
\hline & EmpStatus(2) & .581 & .161 & 12.968 & 1 & .000 & 1.788 & 1.303 & 2.453 \\
\hline & EmpStatus(3) & .265 & .124 & 4.519 & 1 & .034 & 1.303 & 1.021 & 1.663 \\
\hline & Age & .036 & .010 & 13.188 & 1 & .000 & 1.037 & 1.017 & 1.057 \\
\hline & Constant & -.686 & .424 & 2.615 & 1 & .106 & .503 & & \\
\hline
\end{tabular}

$>$ With regards to the education status variable, prospective students already enrolled in other higher education programs are 1.69 times (1/0.592) more likely not to enroll compared to high school seniors.

$>$ Prospective students who have completed other higher education programs are 2.17 times $(1 / 0.462)$ more likely not to enroll compared to high school seniors.

$>$ In terms of marital status, married prospective students are 1.41 times $(1 / 0.711)$ more likely not to enroll compared to those who have never married.

$>$ Prospective students who do not plan to retake the university entrance exam are 3.375 times more likely to enroll compared to those who plan to retake the exam.

$>$ Prospective students who have previously taken the entrance exam three times or more, excepting the current year, in other words, those who have taken the exam for at least four 
times, are 1.6 times $(1 / 0.625)$ more likely not to enroll compared to those who have taken the exam for the first time.

$>$ Self-employed prospective students are 1.457 times more likely to enroll compared to unemployed or retired prospective students.

$>$ Prospective students employed in the public sector are 1.788 times more likely to enroll compared to unemployed or retired prospective students.

$>$ Prospective students employed in the private sector are 1.303 times more likely to enroll compared to unemployed or retired prospective students.

$>$ In terms of age, an increase of one year in the age variable increases the probability of enrollment by a factor of 1.037 .

\section{DISCUSSION AND CONCLUSION}

Distance education is a learning system in which the students are able to participate educational activities by making use of printed materials as well as a rich variety of communicational technologies without a limitation in the time and space, and they have access to the synchronous and asynchronous educational sources and contents (Acik ve Uzaktan Ogrenme Sozlugu, 2018). Its various advantages make it a very important opportunity for the ones who want to have higher education. Gumus and Firat's (2016) study shows that the motives of students who prefer distance are as follows: Flexibility of time, flexibility of space, and new career opportunities.

Aksarayli and Pala (2017) claim that their motives are as follows: "Distance education's contribution to the student's career", "the opportunity to work and study at the same time", "expectation of high academic benefit", and "ease of access".

University candidates who want to study at distance education can register to the system in various ways. The graduates of high schools and their equivalents who want to enroll in departments and programs of Anadolu University Open Education, Economics and Business Administration Faculties are applying to OSYM and participating in the exams (Anadolu University, 2017).

Every year, a part of the students placed to the programs by OSYM prefer not to enroll due to various reasons. In 2015-2016, for example, 31588 of 178229 students (17,72\%) placed to Anadolu University Open Education System preferred not to enroll to the programs they were accepted. Determining the reasons why students prefer to enroll and not to enroll to the programs, and categorizing the students according to their preferences are so crucial to improve the registration system, and to contribute to decision making processes in the administration of the system.

Since the dependent variable of the present study consists of a binary assessment level, i.e. enrolling and not enrolling, binary logistic regression analysis was used. The analysis showed that the registration rate is higher in the group of last-year secondary education students than in the group of secondary education graduates and the ones who already enrolled in or completed higher education. Students enrolled in or completed higher education have the opportunity to enroll the departments and programs of open education system in the Second University context. The findings of the present study showed that $17,3 \%$ of the students placed by OSYM are already enrolled to another higher education program, and $9,2 \%$ of them have completed a higher education program. This group $(26,5 \%)$ do not have to take OSYM exams to be placed in one of the open education programs. Provided that this group of students are informed that they do not have to take the exam, many others who cannot be placed due to capacity issues may well find the opportunity to be enrolled. This sort of registration without examination should be introduced and promoted more efficiently, so that the students who never enrolled or completed any higher education programs may be 
placed and enrolled in the programs. It can be suggested that during OSYM preference process the students must be informed about the secondary university registration conditions.

Darital status also has an influence on the registration decision. Married students are more unlikely to enroll than single students. İt can be presumed that their familial responsibilities result in this decision.

$>$ Students who do not consider taking the university exam for another time are more likely to enroll than the ones who want to do it. Similarly, the students who take the exam for the first time are more willing to enroll compared to ones who had the exam for four times minimum. This may be because the students who take the exam for the first time are more clear about the program they would enroll.

$>$ Working students (either as freelancers, as public sector employees or private sector employees) are more likely to enroll compared to ones who do not work, and the ones who are retired. It can be presumed that the financial status of working students are more convenient than the others, in terms of investing in education. Public sector employees are motivated by the promotion opportunities as a result of the education.

$>$ Older students are more willing to enroll.

The findings demonstrate that the following may be suggested to increase registration figures and to overcome the difficulties students' experience:

Second University is one of the options to enter the Open University system. This option should be promoted in collaboration with OSYM during the preference period, so that applicants who cannot be placed due to program capacities may well find the opportunity to have university education.

$>$ A guidance and counselling service should be established to lead students throughout their educational career, and support them in the preferences. If this system can be accessed by the students before their university education, more students would register on the years they are placed to a program.

> Registration numbers would increase provided that university administration provide some conveniences in payments for the students who are retired, or who do not have a job.

$>$ The regression model may be used to determine the group of students who are more probable not to register, and they might be encouraged by messages during the registration period, and this may increase the number of registered students.

$>$ The logistic regression model could categorize $43,5 \%$ of non-enrolled, and $80,6 \%$ of enrolled students correctly, and the mean correct categorization rate was $66,2 \%$.

$>$ The logistic regression model produced at the end of the analysis was able to explain 16,2\% of the variant in the dependent variable of registration decision. It is clear that the enrollment decision is determined by various other variables besides the ones analyzed in the scope of the present study. Further studies may explore what these variables and their significance levels are.

Author's Note: Anadolu University Scientific Research Projects Commission supported this study under the grant no: $1602 \mathrm{E} 052$ 


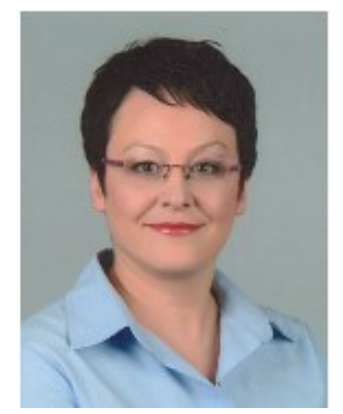

Dr. Oznur OZTURK is an assistant professor at Anadolu University Open Education Faculty. She was graduated with a Bachelor of Science degree in Industrial Engineering from Anadolu University. Then she received her master's and $\mathrm{PhD}$ degrees in Quantitative Methods in Business Administration from Anadolu University. Her fields of interest include simulation, research methods and quantitative decision-making methods.

Dr. Oznur OZTURK

Department of Economics and Administrative Programs, Open Education Faculty Anadolu University, 26470, Eskisehir, Turkey

Phone: +90-335-0580 ext: 2464,

E-mail: oozturk@anadolu.edu.tr

\section{REFERENCES}

Acik ve Uzaktan Ogrenme Sozlugu [Open and Distance Learning Dictionary]. Retrieved July 26, 2018 from http://auosozluk.anadolu.edu.tr/index.php?r=site\%2Findex\#149.

Acikogretim Sistemi [Open Education System]. Retrieved November 6, 2017 from http://anadolu.edu.tr/Acikogretim/Acikogretim-sistemi/Acikogretim-sistemi-1.

Aksarayli, M. ve Pala, O. (2017). Uzaktan Egitimi Tercih Etme Nedenleri ve Basari Arasindaki Iliskinin Kumeleme Analizi ile Incelenmesi [Analysis of Relations Between Reasons of Preference and Success of Distance Education With Clustering Analysis]. Bati Anadolu Egitim Bilimleri Dergisi [Western Anatolia journal of Educational Sciences], 8 (2), 37-48.

Anadolu Universitesi. (2017). 2017-2018 Ogretim Yili Ogrenci Kilavuzu [2017-2018 Academic Year Student Guide]. Retrieved January 24, 2017 from http://anadolu.edu.tr/uploads/anadolu/files/aof_kilavuz/5a127aac93b90.pdf

Albayrak, A. S. (2009). Lojistik Regresyon Analizi [Logistic Regression Analysis]. S. Kalayci, (Ed.), SPSS Uygulamali Cok Degiskenli lstatistik Teknikleri [SPSS Applied Multivariate Statistical Techniquesj(4. Baski) icinde (272-298). Ankara: Asil Yayin Dagitim Ltd. Sti.

Bates, T. (2008). What is Distance Education? Retrieved May 29, 2018 from https://www.tonybates.ca/2008/07/07/what-is-distance-education/

Cokluk, O. (2010). Lojistik Regresyon Analizi: Kavram ve Uygulama [Logistic Regression: Concept and Application]. Kuram ve Uygulamada Egitim Bilimleri [Educational Sciences: Theory \& Practice], (10), 1357-1407.

Cokluk, O., Sekercioglu, G. ve Buyukozturk, S. (2014). Sosyal Bilimler 1Cin Cok Degiskenli lstatistik SPSS ve LISREL Uygulamalari [Multivariate Statistics for Social Sciences SPSS and LISREL Applications] (3. Baski). Ankara: Pegem Akademi.

Field, Andy. (2013). Discovering Statistics Using IBM SPSS Statistics (4th Edition). London: Sage Publications. 
Gumus, M. ve Firat, M. (2016). Acik ve uzaktan ogrenmenin tercih edilme nedenlerinin belirlenmesi [Determination of reasons for preferring open and distance learning]. Acikogretim Uygulamalari ve Arastirmalari Dergisi [AUAd], 2 (4), 158-168.

Hair, J. F., Black, W. C., Babin, B. J. ve Anderson, R. E. (2010). Multivariate Data Analysis A Global Perspective (Seventh Edition). Upper Saddle River, NJ: Pearson.

Ozdamar, Kazim. (2015). Paket Programlar ile 1statistiksel Veri Analizi -1 MINITAB 17-1BM SPSS 22 [Statistical Data Analysis with Packet Programs-1 MINITAB 17-1BM SPSS 22]. (10. Baski). Ankara: Nisan Kitabevi Yayinlari.

Sahin, T. (2017). Anadolu Universitesi Acikogretim Sisteminin Tarihsel Gelisimi (1982-2015) Kronolojisi [The Historical Development of the Anadolu University Open Education System (1982-2015) Chronology]. Eskisehir: Anadolu Universitesi Basimevi.

Tabachnick, B. G. ve Fidell, L. S. (2001). Using Multivariate Statistics (4th Edition). USA: Allyn \& Bacon.

Tatlidil, H. (1996). Uygulamaii Cok Degiskenli lstatistiksel Analiz [Applied Multivariate Statistical Analysis]. (Ikinci Baski). Ankara: Akademi Matbaasi.

Ugurlu, S. (2016). Lojistik Regresyon Analizi [Logistic Regression Analysis]. C. O. Guzeller, (Ed.), Herkes lcin Cok Degiskenli lstatistik [Multivariate Statistics for Everyone]. (1. Baski) icinde (131-149). Ankara: Maya Akademi. 


\section{APPENDICES}

Appendix 1: Independent Variables Used in the Study and Their Levels of Measurement

\begin{tabular}{|c|c|c|c|}
\hline $\begin{array}{l}\text { Var. } \\
\text { Name }\end{array}$ & Explanation & $\begin{array}{l}\text { Var. } \\
\text { Name }\end{array}$ & Explanation \\
\hline $\mathrm{X}_{1}$ & $\begin{array}{l}\text { Gender } \\
\text { - Male } \\
\text { - Female }\end{array}$ & $\mathrm{X}_{8}$ & $\begin{array}{l}\text { How many times have you taken } \\
\text { the university entrance exam, } \\
\text { excepting the current year } \\
\text { - None } \\
\text { - } 1 \text { time } \\
\text { - } 2 \text { times } \\
\text { - } 3 \text { times or more }\end{array}$ \\
\hline & $\begin{array}{l}\text { Education status } \\
\text { - High school senior }\end{array}$ & & \\
\hline $\mathrm{X}_{2}$ & $\begin{array}{l}\text { - High school graduate, not placed in a } \\
\text { higher education program before } \\
\text { - Placed in a higher education program by } \\
\text { OSYM (including admissions without } \\
\text { entrance exam) but did not enroll } \\
\text { - Enrolled in a higher education program } \\
\text { - Completed a higher education program }\end{array}$ & $\mathrm{X}_{9}$ & $\begin{array}{l}\text { Employment status } \\
\text { - Unemployed / Retired } \\
\text { - Self-employed } \\
\text { - Employed in the public } \\
\text { sector } \\
\text { - Employed in the private } \\
\text { sector }\end{array}$ \\
\hline
\end{tabular}

- Dropped out of a higher education program

Marital Status

$\mathrm{X}_{3}$

- Never married

- Married

- Divorced / Widowed

$$
\begin{aligned}
& \text { Years employed } \\
& \text { - } 5 \text { years or less } \\
& \text { - 6-10 years } \\
& \text { - 11-15 years } \\
& \text { - } 16 \text { years or more } \\
& \text { - Unemployed / Retired } \\
& \text { Monthly household income }
\end{aligned}
$$

Number of children in the family including the respondent

- 1

$\mathrm{X}_{4} \bullet 2$

- 3

- 4

- 5 or more

Mother's education level

- İlliterate

- Literate but no school

$\mathrm{X}_{5}$ - Elementary School

- Middle School

- High School

- At least some college 
Father's education level

- İlliterate

- Literate but no school

$\mathrm{X}_{6} \quad-\quad$ Elementary School

- Middle School

- High School

- At least some college

Do you plan to retake the university entrance exam

$\mathrm{X}_{7}$

- Yes

- $\mathrm{No}$
Place of Residence

- Marmara Region

- Black Sea Region

- Aegean Region

$\mathrm{X}_{13} \quad$ - Central Anatolia Region

- Eastern Anatolia Region

- Mediterranean Region

- Southeastern Anatolia Region

Appendix 2. Frequency Table of Independent Variables

\begin{tabular}{|c|c|c|c|}
\hline Variable & Explanation & Frequency & Percentage \\
\hline \multirow{2}{*}{ Gender } & Male & 991 & 54.2 \\
\hline & Female & 838 & 45.8 \\
\hline \multirow{6}{*}{ Education status } & High school senior & 390 & 21.3 \\
\hline & $\begin{array}{l}\text { High school graduate, not placed in a higher } \\
\text { education program before }\end{array}$ & 731 & 40.0 \\
\hline & $\begin{array}{l}\text { Placed in a higher education program by OSYM } \\
\text { (including admissions without entrance exam) but } \\
\text { did not enroll }\end{array}$ & 79 & 4.3 \\
\hline & Enrolled in a higher education program & 316 & 17.3 \\
\hline & Completed a higher education program & 168 & 9.2 \\
\hline & Dropped out of a higher education program & 145 & 7.9 \\
\hline \multirow{4}{*}{ Marital status } & Never married & 1053 & 57.6 \\
\hline & Married & 723 & 39.5 \\
\hline & Divorced / Widowed & 53 & 2.9 \\
\hline & 1 & 137 & 7.5 \\
\hline \multirow{4}{*}{$\begin{array}{l}\text { Number of children in } \\
\text { the family (including } \\
\text { the respondent) }\end{array}$} & 2 & 465 & 25.4 \\
\hline & 3 & 502 & 27.4 \\
\hline & 4 & 315 & 17.2 \\
\hline & 5 or more & 410 & 22.4 \\
\hline \multirow{7}{*}{$\begin{array}{l}\text { Mother's education } \\
\text { level }\end{array}$} & İlliterate & 291 & 15.9 \\
\hline & Literate but no school & 201 & 11.0 \\
\hline & Elementary School & 856 & 46.8 \\
\hline & Middle School & 228 & 12.5 \\
\hline & High School & 199 & 10.9 \\
\hline & At least some college & 54 & 3.0 \\
\hline & İlliterate & 45 & 2.5 \\
\hline \multirow{5}{*}{$\begin{array}{l}\text { Father's education } \\
\text { level }\end{array}$} & Literate but no school & 128 & 7.0 \\
\hline & Elementary School & 804 & 44.0 \\
\hline & Middle School & 303 & 16.6 \\
\hline & High School & 393 & 21.5 \\
\hline & At least some college & 156 & 8.5 \\
\hline \multirow{3}{*}{$\begin{array}{l}\text { Plans to retake the } \\
\text { exam }\end{array}$} & Yes & 1189 & 65.0 \\
\hline & No & 640 & 35.0 \\
\hline & Never & 337 & 18.4 \\
\hline
\end{tabular}




\begin{tabular}{|c|c|c|c|}
\hline \multirow{3}{*}{$\begin{array}{l}\text { How many times the } \\
\text { exam was taken } \\
\text { (excluding the current } \\
\text { year) }\end{array}$} & 1 time & 477 & 26.1 \\
\hline & 2 times & 482 & 26.4 \\
\hline & 3 times or more & 533 & 29.1 \\
\hline \multirow{4}{*}{ Employment status } & Unemployed / Retired & 557 & 30.5 \\
\hline & Self-employed & 184 & 10.1 \\
\hline & Employed in the public sector & 373 & 20.4 \\
\hline & Employed in the private sector & 715 & 39.1 \\
\hline \multirow{6}{*}{ Years employed } & 5 years or less & 674 & 36.9 \\
\hline & $6-10$ years & 259 & 14.2 \\
\hline & $11-15$ years & 160 & 8.7 \\
\hline & 16 years or more & 179 & 9.8 \\
\hline & Unemployed / Retired & 557 & 30.5 \\
\hline & Less than 1,000 Turkish liras & 276 & 15.1 \\
\hline \multirow{3}{*}{$\begin{array}{l}\text { Monthly household } \\
\text { income }\end{array}$} & 1,000-2,000 Turkish liras & 804 & 44.0 \\
\hline & 2,001-5,000 Turkish liras & 662 & 36.2 \\
\hline & More than 5000 Turkish liras & 87 & 4.8 \\
\hline \multirow{7}{*}{ Place of Residence } & Marmara Region & 559 & 30.6 \\
\hline & Black Sea Region & 177 & 9.7 \\
\hline & Aegean Region & 221 & 12.1 \\
\hline & Central Anatolia Region & 369 & 20.2 \\
\hline & Eastern Anatolia Region & 125 & 6.8 \\
\hline & Mediterranean Region & 226 & 12.4 \\
\hline & Southeastern Anatolia Region & 152 & 8.3 \\
\hline \multirow[t]{7}{*}{ Age } & & \multicolumn{2}{|c|}{ Descriptive Statistics } \\
\hline & Minimum value & 18 & \\
\hline & Maximum value & 62 & \\
\hline & Median & 25 & \\
\hline & Mode & 21 & \\
\hline & Mean & 27.67 & \\
\hline & Standard deviation & 8.04 & \\
\hline
\end{tabular}

